\title{
EXPERIENCES OF SOUTH AFRICAN SOCIAL WORKERS IN THE UNITED KINGDOM
}

\section{S Naidoo, M Kasiram}

\section{INTRODUCTION}

This article forms the third phase of a research study conducted to explore the exodus of social workers from South Africa to the United Kingdom (UK). Already reported in a previous article (Naidoo \& Kasiram, 2003) are phases one and two of the study wherein the views of two sample groups were explored on relocation in South Africa. This third phase explored the needs, problems and benefits experienced by social workers working in the UK. Social workers abroad were asked about the following questions:

- What made social work practice in South Africa problematic?

- Was their South African education and training relevant?

- What were the benefits of working in the UK?

- What were the challenges to working in the UK?

- What suggestions did they have for the survival of social work in South Africa?

\section{RESEARCH METHODOLOGY}

As opposed to the quantitative nature of the earlier phases, this phase of the study was essentially qualitative and exploratory, utilising focus groups to collect data. Neumann (2000:420) points out that themes and concepts, rather than variables, serve as the analytical tools for qualitative study. In this phase, themes served as a map for the path that was followed by the researchers in eliciting the views of respondents' work experience in South Africa and in the UK.

\section{The sample}

One of the authors worked for a recruitment agency in South Africa and had interviewed social workers wishing to relocate. These workers were then contacted to participate in the third phase of the research, thus purposive sampling was employed. Social workers from London and surrounds who were able to travel to a venue in Wandsworth participated in focus group discussions held in December 2001. Three focus groups comprising 10 members $(\mathrm{N}=30)$ participated in this phase.

\section{Data analysis}

Content analysis was employed in analysing data. Data reduction was a challenge as the sample had an opportunity to meet other South Africans to share common experiences after varying periods of stay in the UK. Much data, both solicited and unsolicited was forthcoming. According to Krueger (1994:152), the "... analysis process in focus groups is like detective work". Clues that recurred in the discussions allowed data to be classified under the themes mentioned earlier.

In accord with the qualitative nature of this study, responses were sometimes recorded in respondents' own words.

\section{RESULTS AND DISCUSSION}

\section{Sample details}

Respondents were both male and female. Females comprised $83 \%(\mathrm{~N}=25)$, this being the majority of the sample, while $17 \%(\mathrm{~N}=5)$ were male. That females dominated is consistent not only with 
the trend noted in the previous two phases of the study but is also in accord with gender demographics of social workers in South Africa. Social work is a female-dominated profession.

As regards marital status, more respondents (43\%) were single than married (37\%). The remaining $20 \%$ were either divorced or widowed. Working in the UK would seem to be a more viable option for single social workers but is reflected in only a slightly higher percentage being single. A substantial percentage (37\%) of married social workers sought relocation/work in the UK. Often the long term visa (five-year permit) allowed dependants to be included in permits, unlike the short term two-year working holiday visa, allowing relocation of entire families. This information is significant in exploring motivation to work in the UK. The study indicated that $43 \%$ of the respondents in this phase had no dependants, while $42 \%$ had between one and two dependants. Thus, having dependants did not serve as a mitigating factor in preventing workers leaving for the UK.

The majority of respondents were awarded long term visas. It was found that $65 \%$ of the respondents relocated to the UK on a five-year working permit, while only $35 \%$ were on a twoyear holiday visa. That long term visas were preferred could point to respondents considering permanent residence in the UK. Possibly, realities of poverty, violence and crime in South Africa; high unmanageable workloads; limited upward mobility and frustrations with the profession have led social workers opting for a longer term visa, as evidenced in the earlier report (Naidoo \& Kasiram, 2003). Social workers opting for long term visas took a wealth of experience and knowledge to the UK. White (2001) agreed, noting that South African social workers were welcome in the UK on long placements because they brought a fresh perspective and valuable experience. It would appear that there is a high attrition rate in social work numbers in the UK, hence the need to supplement numbers through recruitment. That the UK trains social workers for practice, but loses them to other better paying jobs is noted (Lawrence, Dustin, Kasiram \& Partab, 2003). Both experienced and inexperienced social workers are recruited from South Africa, as evidenced in recruitment agencies requesting Universities for time and space to recruit from their final year student cohorts as well as the many adverts in local newspapers seeking experienced social workers. Perhaps South African social workers are attracted to the salary in the UK which is considerably higher than that in South Africa. Also, with South African unemployment rates being high, the South African social worker may opt for both the assurance of a job and a better salary overseas.

Years of experience of respondents is illustrated in Figure 1. The majority $(\mathrm{N}=20)$ of the respondents had more than seven years experience. This trend was also evident in phase one, with experienced social workers expressing their intention to leave for the UK. Gathiram (2000) too, found that many experienced social workers were frustrated, citing stagnation and limited upward mobility as reasons for leaving South Africa's workforce.

No specific questions were posed to respondents about their age or race; this information may have been useful in better interpreting findings against these characteristics. 


\section{FIGURE 1 \\ YEARS OF EXPERIENCE AS A SOCIAL WORKER}

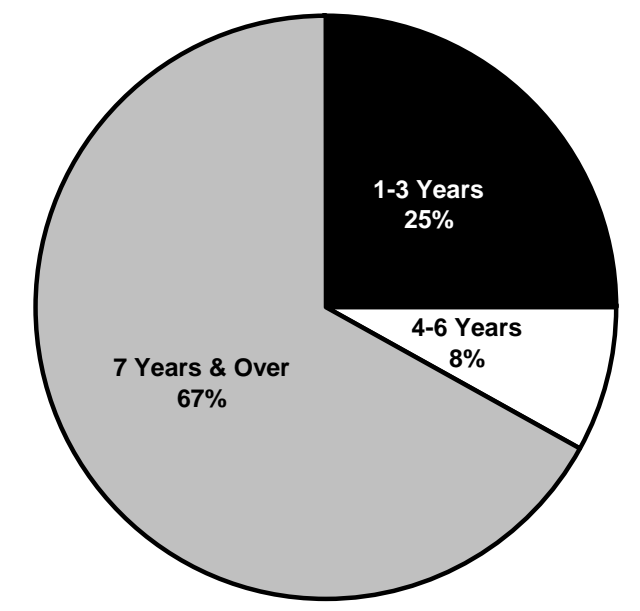

PROBLEMATIC WORK EXPERIENCES IN SOUTH AFRICA

Respondents cited many work frustrations whilst in South Africa.

\section{Workload}

Social workers described high caseloads in South Africa as "most frustrating". One social worker reported: "Often I dealt with 80 cases at any one time, with approximately $70 \%$ involving statutory work." Other concerns were that there was too much to do in a single day. Respondents described themselves as being inundated, as "crisis workers" rather than professional social workers. Recording was reportedly neglected, theoretical planning was often absent and investigations were superficial. It was almost impossible to offer other methods of social work. These findings are supported by Gray and Bernstein (1994) and Dominelli (1996) who state that integrated practice is a misnomer because social workers cannot work at the individual, group and community level simultaneously and that if there were specialization within the team, practice would improve. However this is a far fetched ideal in South Africa, given the problem of staff shortages.

Ross and Fridjhon (1995) confirm that when there are staff shortages, the problem of high caseloads is exacerbated. These concerns account not only for job dissatisfaction leading to relocation, but also for the "de-professionalization" of social work. Social workers compared their South African experience to the one in the UK where 20 cases were considered high and emotionally draining (Pritchard, 2000). The standard of work in the UK was described as being good, involving in-depth assessment and intervention. In addition, ample support was received from supervisors and managers.

Other complaints were of interference and unreasonable demands by senior staff and Boards of Management, a finding supported by Otte (2003) who complained that bureaucratic requirements, such as updating statistics, stole the worker's time. Lombard (2000) and Collings and Murray (1996) found similar frustrations of high workloads and accompanying stress, leading to crisis work and neglect of administrative work and record keeping. Respondents viewed work pressures and increased workloads as related to the socio-economic conditions prevalent in South Africa, particularly among the poor and unemployed, where the demand for services has increased to the 
extent that, social workers are neither able to cope with demand nor provide effective services (Van Biljon, 1994).

\section{Funding and resources}

Another frustration reported by respondents whilst in South Africa was the lack of resources in South Africa. These were cited as the main obstacle to adopting a developmental focus to social work (Louw, 1994; Kaseka \& Gumbo, 1998; Ross, 1996). Respondents reported that resources such as cell phones and well-serviced, reliable cars were essential, but unavailable. Furthermore, adequate physical, financial and human resources had an urban bias. According to Neugoboren (1991:293), technology promotes co-ordination and quality services, but deprived agencies and communities are further disadvantaged because of lack of technology.

Respondents complained that the vast geographical area served by their agencies coupled with reduced subsidies, placed unrealistic demands on them. Lack of community support, uncooperative clients and limited funds cumulatively presented as insurmountable obstacles and contributed to decisions to leave South Africa.

\section{The socio economic context}

The way social workers enter communities predicts the success of community projects. Respondents reported that in South Africa they often experienced resistance in entering high risk areas and needed police escort. This was perceived as being counter productive to the bottom-up approach advocated in successful developmental practice. In a study carried out by Ross and Fridjohn (1995:275), it was also found that $84,6 \%$ of the respondents identified socio-economic and politico-cultural stressors in their work. These included unemployment, retrenchment and poverty in clients, colleagues and themselves leading to insecurity, anxiety and pre-occupation with survival. This contributed to their decision to leave the country.

\section{Service conditions and salaries}

All respondents reported dissatisfaction with service conditions especially salaries. They opted to work in the UK because earning in pounds, good service conditions and higher salaries were assured. They felt that discrepancies in the salaries of governmental and non-governmental organisations in South Africa were frustrating (Gray \& Van Rooyen, 2000). Consequently, there was an ever present view that better opportunities such as those in the UK should be considered seriously.

Social workers complained that "...often we felt inferior to other qualified persons, since our salaries were considerably lower". These frustrations are similar to those from respondents in the earlier phases of the study (Naidoo \& Kasiram, 2003). The Gray and Van Rooyen (2000) study also reported that concerns of social workers were mainly their low status and poor salaries, relative to other professionals. It seems that although job satisfaction and good working conditions can, to some extent, make up for poor salaries, this is absent in South Africa, leading to job movement, high staff turnover and relocation.

\section{RELEVANCE OF TRAINING}

Respondents were asked to comment on the relevance of their training for social work in the UK and the South African context. For work in the UK, respondents were positive indicating that their South African training provided a solid foundation and was comprehensive (four year degree) in comparison to the academic training offered in the UK (2,5 year diploma). South African training was also regarded as being "academic" and theoretical as compared to UK training that was considered to be too "practice-orientated". 
Respondents reported that the image of the social work profession in the UK is negative, owing to poor training, being viewed as a "hobby" before a person moves onto a "proper job". Other positive comments were that South African training equipped them for multi-cultural practice, for coping with administration and report writing. Perhaps the criticism by Mazibuko, McKendrick and Patel (1992) holds true today that the South African curriculum is concerned with the preparation of highly-skilled social workers to deal with first world problems, given their easy adjustment to social work practice in the UK context. This criticism suggests that South African social workers are not adequately trained to meet South African realities such as poverty and disadvantage, a strong possibility given that this is often an expressed concern at the Joint Universities Committee meetings (2002, 2003, 2004).

Several respondents criticised their training for the South African context, with one respondent retorting: "Heavens, no!" Social workers claimed that they were unable to handle social problems such as poverty, crime, violence and HIV/AIDS as academic curricula dealt superficially with these topics (McKendrick, 1994; Ramphal \& Moonilall, 1993; Van Schalkwyk, 1997). Further, respondents indicated that university practice placements were urban-biased in "privileged organisations" where harsh South African realities were not experienced. Yet, these respondents also stated that their training equipped them for working with diversity. Perhaps this may be explained by the range of practice placements offering diverse experiences despite insufficient attention to placements in rural and poor settings. Social workers also criticized the curriculum for its focus on clinical work which they felt was inappropriate in South Africa but useful for the UK.

Newly-qualified social workers however felt their training was relevant and indicated that curricula had incorporated a developmental focus, suggesting that training has, in the last few years transformed to some extent. However, more transformation seems necessary as not all Universities have committed to transform equally, a finding supported by Mamphiswana and Noyoo (2000:24). It is important that tertiary institutions are not guilty of "training social workers for Britain” (Lombard, 2000:330).

\section{BENEFITS OF WORKING IN THE UK}

Respondents were asked to elaborate on the benefits of working in the UK.

\section{Resources and teamwork}

All respondents agreed that compared to South Africa, the UK had many accessible resources. Many found that the requirement of team involvement was beneficial as workers did not hold sole responsibility for decisions. This was perceived as reducing stress and increasing support to the client system. Otte (2003) noted that in South Africa "...frustration and stress was experienced since teamwork was non existent". Further, very different from their South African experience, respondents reported that all social work managers in the UK were responsible for statutory cases. In addition, social workers received support from a legal representative (lawyer) in compiling reports and in presenting cases to court. All respondents agreed that working in the UK brought them "peace of mind" because of procedures and policies that ensured safe practice. These included secure, monitored, interviewing rooms with panic buttons.

\section{Upward mobility}

Respondents were pleased with opportunities for upward mobility in the UK and confirmed that limited opportunities for promotion in South Africa contributed to their leaving (Naidoo \& Kasiram, 2003). Many reported being more dedicated and motivated to study further since being promoted in the UK. It was also reported that neither securing a job nor upward mobility was dependant on race, age or experience as in South Africa. This may well be because of acute staff 
shortages in the UK. Several respondents claimed that they had been unsuccessful in obtaining permanent employment in South Africa as they were told that they did not have adequate experience, were of the wrong race group or age. By implication (since age and race were not determined) respondents were generally young, White, Indian or Coloured. Therefore discriminatory policies such as the affirmative action policy in South Africa may contribute to the brain drain in the country.

\section{Training and professional development}

All respondents asserted that infrastructural support, resources and training for social workers in the UK were excellent. Social workers were afforded comprehensive, on going training and professional development which was encouraged and paid for by employers. A comprehensive programme was compiled annually to accommodate needs such as report-writing, computer skills and theoretical updates. All training was supported by literature and manuals, and was conducted professionally with attendees given certificates for attendance. It was clear that the UK encouraged development of good social work practice by promoting continuous professional development.

Supervision was also discussed under this theme. Respondents reported that supervision commenced weekly but later continued on a fortnightly basis. Respondents complained that back home it was poorly conducted, ineffectual and a source of stress (Simpson, 2002). Otte (2003) too, described feeling “...bullied and emotionally blackmailed" during supervision. According to Adams, Dominelli and Payne (2002), supervision, if properly used, can become a management tool for accountability and efficiency, and prevention of burn out. It thus needs to become a core component of social work practice in South Africa.

\section{Working conditions}

Not surprisingly, all respondents reported that their working conditions and salaries were definitely better in the UK than in South Africa. The salaries offered in the UK were competitive and equivalent to other professions with similar years of qualification. All indicated that relocating to the UK was mainly for financial gain. Many wanted to save and then return to South Africa with the pounds, either to open up a business or venture into another career. Respondents also enjoyed working benefits such as pension, medical aid (National Insurance Fund) and the London weighting allowance (an allowance provided to workers living in inner London to compensate for high rentals). Social workers were also allowed up to eight days a year dependency leave to support parents with young children who were ill. There was also opportunity for working flexitime, allowing workers to work around personal needs and preferences. Social workers further appreciated the special benefits attached to attending training with time-off and four days study leave and subsistence and car allowances. They appreciated having access to in-house libraries, cell phones, administrative staff (typist for each team), dictaphones, and computers with internet and e-mail.

\section{Personal gains}

Many UK social workers reported that one of the greatest gains was the opportunity to travel across Europe at affordable rates. Overall they believed that quality of life had improved and that they no longer lived in fear of being hijacked, robbed or murdered. Relocation had also taught them independence. For their families, benefits were a safer environment, better educational facilities and reliable aftercare. 


\section{Challenges in the UK}

Respondents shared several concerns regarding work in the UK, including social isolation, neglect of cultural and spiritual needs, work structures, accommodation and the climate. Most of the respondents reported that relocating to the UK meant social isolation from family and friends. This isolation was acutely felt during family crises. They missed family who provided loving after care as they now had to pay dearly for formal, after care services in the UK.

Most respondents indicated that by relocating, their cultural and spiritual needs were neglected. Often they could not practise cultural rituals since many lived away from worshipping areas. They feared that their children were losing out culturally and spiritually. Emigration might have financial rewards, and greater safety and security, but it comes at a price of limited access to social, cultural, spiritual and family supports.

They complained about work structures in the UK which were very bureaucratic, stifling and frustrating. Work was stressful because of the "massive amounts of paper and computer work" that they had to complete. Many social workers were of the opinion that the administrative systems and procedures served more to protect the agency than the client. Other work - related challenges included staff in the UK being cold, unfriendly, racist and not accommodating. This is disconcerting since anti-oppressive social work practice is advocated in the UK (Kasiram, Partab, Lawrence \& Dustin, 2002). In addition, UK clients were viewed as difficult, unappreciative, rude and racist. Clients in the UK were encouraged to complain if they were dissatisfied with services. The benefit of this was that clients became empowered to participate in their treatment but this was used to verbally abuse and threaten social workers. Other negative comments were in relation to open plan offices that meant a lack of privacy and use of public transport for home visits. Team managers were also perceived as being threatened by their sophisticated South African training. Yet they were perceived as offering superior supervisory functions compared to their South African counterparts. It was difficult to fathom how effective supervision was possible in a climate where professional jealousy existed on a covert or overt level. Interestingly, no-one complained of using casework as the primary method of service delivery.

\section{Accommodation/Climate}

Respondents complained that good accommodation was very expensive and that they often had to accept unsuitable, cramped living arrangements. As for the weather, it was dreary and miserable and they missed the South African sun and blue skies.

\section{Returning to South Africa}

Respondents were asked whether they had any intention of returning to practise social work in South Africa. The majority (90\%) indicated that they would return, but not as social workers. They wanted to change their careers on their return and go into business, private practice or to become consultants. Only $10 \%$ of the respondents were ready to give South African social work another chance.

\section{Suggestions for social work to survive in South Africa}

When respondents were asked about the survival of social work in South Africa, they predictably suggested reducing workloads, improving service conditions and infrastructural support, a safer work environment and changes to academic curricula. They also suggested that social workers participate in policy-making, that there be unity among social workers and that professional associations address the profession's needs urgently. The authors are of the opinion that policy makers, tertiary institutions, employers and associations all need to address the problems faced by 
the profession, but if social workers themselves are not proactive, then their voices will never be heard, little will be accomplished, and the social work profession could face a bleak future.

\section{Conclusions and recommendations}

South Africa requires an enthusiastic and optimistic workforce. The study concluded that job dissatisfaction and occupational stress were aggravated by low salaries and poor working conditions, all of which contributed to the exodus of social workers from South Africa. Welfare could adopt ideas from Health to reduce the exodus through higher salaries, attractive benefits and a "golden hello" to re-attract professionals. Those who have relocated to the UK realize soon enough that social work is indeed not a well paying job in the UK, so it will serve the profession to re-examine salaries and other work benefits in South Africa. Flexible contracts, continuous professional development opportunities, opportunities for upward mobility and improved supervision and management could go a long way towards retaining social workers in the country. The profession could also consider the feasibility of compulsory community service to delay the departure of social workers.

Findings suggest that burnout is a problem for South African social workers. Their experiences in the UK suggest greater work satisfaction, despite the impersonality of the work environment due to inter alia flexible working hours, leave to accommodate family responsibility and authorised voluntary breaks. Although UK social workers do not appear to remain in the profession, these "perks" are meaningful to the South African social workers, suggesting the need for the profession to urgently address the problem of burnout in South Africa. Supervision was not seen as stressful but rather as offering advice, support and opportunities for reflection. To improve the work environment in South Africa, and thus to keep its social workers, agencies should establish human resource departments for staff development. Staff development could involve subscribing to journals (Van Zyl \& Botha, 1997), attendance at short courses and incentives for the completion of further study and higher degrees.

Organisations should minimise stressors by promoting a positive culture and staff care as a reality rather than mere rhetoric. Ways in which this may be accomplished include offices painted in calm-inducing colours; pictures depicting creativity and freshness; time off for staff get-togethers; team-building sessions; involving workers in policies; "climate surveys" such as attitude surveys to understand workers' reactions and preferences and recognition for work excellence.

The study pointed to limited use of the developmental approach, thereby suggesting that social workers are not meaningfully addressing problems such as poverty and disadvantage. Thus, it is recommended that social workers actively engage in policy, publicise successes and demonstrate that clinical and developmental aspects of work are not necessarily antithetical to each other. Training institutions are also urged to transform curricula to help workers cope with practice realities. Workers should conduct impact studies to evaluate and refine programmes and engage in multi-sectoral negotiations to address problems comprehensively.

Since safety and security was found to contribute to decisions to leave South Africa, it is suggested that a partnership be forged with the police to enjoy their protection; secure satellite offices set up; cell-phones, reliable vehicles and two-way radio communication be available and unions lobby for safer working conditions.

Unmanageable case and workloads contributed to decisions to leave the South African workforce, whilst a manageable load in the UK was viewed as promoting job satisfaction. It is thus recommended that more workers be employed, there be supervision and support to deal with high workloads, use made of social auxiliary workers and that workers are offered time management 
skills. Finally, campaigns to re-attract social workers who have relocated should target their need for family and support networks, cultural and spiritual fulfilment, spacious accommodation and the glorious South African weather!

\section{REFERENCES}

ADAMS, R., DOMINELLI, L. \& PAYNE, M. 2002. Social work themes, issues and critical debates $\left(2^{\text {nd }}\right.$ ed). Hampshire: Palgrave.

COLLINGS, J.A. \& MURRAY, P.J. 1996. Predictors of stress among social workers: An empirical study. British Journal of Social Work, 26:375-387.

DOMINELLI, L. 1996. The future of social work education: Beyond the state of the art. Scandinavian Journal of Social Welfare, 5:194-201.

GATHIRAM, N. 2000. Social policy: Transformation and delivery. Study of welfare agencies in KZN. Durban: University of Durban-Westville. (Unpublished Doctoral Thesis)

GRAY, M.M.A. \& BERNSTEIN, A.J. 1994. Integrated practice: A misnomer in social work. Social Work/Maatskaplike Werk, 30(3):199-207.

GRAY, M.M.A. \& VAN ROOYEN, C.A.J. 2000. Social work political participation: A South African study. Social Work/Maatskaplike Werk, 36(2):180-192.

KASIRAM, M.I., PARTAB, R., LAWRENCE, S. \& DUSTIN, D. 2002. Evaluating social work programmes at the Universities of Durban Westville and North London: Articulation and partnering possibilities. Paper presented at the Joint Universities Committees Annual Conference on Re-Positioning Social Work within a Changing Environment, Potchefstroom University.

KASEKA, E. \& GUMBO, P. 1998. The state and dynamics of social policy practice and research in Zimbabwe. Journal of Social Development in Africa, 13(2):21-34.

KRUEGER, R.A. 1994. Focus groups. A practical guide for applied research ( $2^{\text {nd }}$ ed). Newbury Park: Sage Publications.

LAWRENCE, S., DUSTIN, D., KASIRAM, M. \& PARTAB, R. 2003. Exploring partnership: Student evaluations of interpersonal exchanges in London and Durban. In: DOMINELLI, L. Broadening horizons. UK: Bookpoint Limited Publishers.

LOMBARD, A. 2000. The professional status of social work. Social Work/Maatskaplike Werk, 36(4):311-350.

LOUW, L.R. 1994. Community intervention in a society in transition: Social action. Social Work/Maatskaplike Werk, 30(4):295-298.

MAMPHISWANA, D. \& NOYOO, N. 2000. Social work education in a changing socio-political and economic dispensation: Perspectives from South Africa, International Social Work, 43(1):21-32.

MAZIBUKO, F.N.M., McKENDRICK, B.W. \& PATEL, L. 1992. Social work in South Africa: Coping with Apartheid and change. In: HOKENSTAD, M.C., KHINDUKA, S.K. \& MIDGLEY, J. (eds) Profiles in international social work. Washington DC: NASW Press. 
McKENDRICK, B.W. 1994. The transition to practice: How employable are new graduates. Social Work/Maatskaplike Werk, 30(4):310-318.

NAIDOO, S. \& KASIRAM, M. 2002. Social work in South Africa: Quo Vadis. Paper presented at the Joint Universities Committees Annual Conference on Re-Positioning Social Work within a Changing Environment, Potchefstroom University.

NAIDOO, S. \& KASIRAM, M. 2003 Social work in South Africa: Quo Vadis? Social Work/Maatskaplike Werk, 39(4):372-380.

NEUGEBOREN, B. 1991. Organization, policy and practice in the human services. New York: Haworth Press Inc.

NEUMANN, W.I. 2000. Social research methods: Qualitative and quantitative approaches $\left(4^{\text {th }}\right.$ ed). Boston MA: Allyn \& Bacon Publishers.

OTTE, B. 2003. Why consider working overseas? Paper presented at the Joint Universities Committees Annual Conference on Contemporary Issues in Social Work, Pretoria University.

PRITCHARD, J. 2000. Good practice in supervision: Statutory and voluntary organisations. Gateshead England: Athenaeum Press.

RAMPHAL, R. \& MOONILAL, R. 1993. Can social work agencies meet the challenges in Post Apartheid South Africa? A planners perspective. Social Work/Maatskaplike Werk, 29(4):363370 .

ROSS, E. 1996. How South African social workers cope with occupational stress. Social Work/Maatskaplike Werk, 32(2):97-111.

ROSS, E. 1996. The impact of societal factors on South African social workers experience of occupational stress. Social Work/Maatskaplike Werk, 32(1):75-88.

ROSS, E. \& FRIDJHON, P. 1995. Burnout: A smouldering problem among South African social workers? Social Work/Maatskaplike Werk, 31(3):265-279.

SIMPSON, B. 2002. The place of supervision in social work practice: For better or for worse? Paper presented at the Joint Universities Committees Annual Conference on RePositioning Social Work within a Changing Environment, Potchefstroom University.

VAN BILJON, R. 1994. The challenge of quality assurance in the education and training of social work managers. Social Work/Maatskaplike Werk, 30(2):185-198.

VAN SCHALKWYK, H.M. 1997. A participatory partnership model for social work in informal settlements. Johannesburg: Rand Afrikaans University. (Unpublished Doctoral Thesis)

VAN ZYL, R. \& BOTHA, N.J. 1997. The professional development of social workers. Social Work/Maatskaplike Werk, 33(1):24-35.

WHITE, M. 2001. Desperate measures for desperate times. Care and Health Magazine, 12 November.

Dr Samantha Naidoo, Social Worker and Professor Madhu Kasiram, School of Social Work and Community Development, University of KwaZulu-Natal, Durban, South Africa. 